\title{
PENGARUH KETIDAKPUASAN KONSUMEN, KARAKTERISTIK KATEGORI PRODUK HP, TERHADAP KEPUTUSAN PERPINDAHAN MEREK PADA MAHASISWA REGULAR PROGRAM STUDI MANAJEMEN ANGKATAN 2014-2015 STIE "KBP" PADANG
}

\author{
Ari Anggara, Riri Mayliza \\ Sekolah Tinggi Ilmu Ekonomi KBP \\ aanggara530@gmail.com \\ ririmayliza@akbpstie.ac.id
}

\begin{abstract}
This study aimed to determine the effect of consumer dissatisfaction and characteristics of the product category $h p$ to brand switching decision on a regular student workforce management courses 2014-2015 STIE "KBP" Padang. The variable in this study is the Consumer Dissatisfaction (X1), Characteristics Product Categories Hp (X2) and Decision Switching Brands (Y). The sample used is 56 students, the sampling technique uses saturated sampling method. Data collection used a questionnaire, while data analysis techniques were performed using multiple linear regression analysis. The results showed that the variable consumer dissatisfaction had a negative effect $(-2.123<2.021)$ and was significant $(0.038>0.05)$ on the decision to move the brand. Variable characteristics of cellphone product characteristics have a negative effect ($1.013<2,021)$ and are not significant $(0,316>0,05)$ on brand transfer decisions. It is expected that the next researcher will be able to use research as a reference which will later provide a comparison in conducting further research. In terms of the number of variables, which in this study, the researchers only use three variables: Consumer Dissatisfaction and Characteristics Product Categories Hp as the dependent variable, and Decision Switching brands as independent variables. Thus, the next researcher can add other variables or intervening variables in the next research process.
\end{abstract}

Keywords: Consumer Dissatisfaction, Characteristics of HP Product Categories, Brand Transfer Decisions

\section{PENDAHULUAN}

Perusahaan teknologi dibidang komunikasi saat ini mengalami kemajuan yang amat pesat. Hal ini seiring dengan perubahan kebutuhan masyarakat akan jasa telekomunikasi yang semakin kompleks. Dengan tersedianya jaringan telekomunikasi yang baik, maka dapat mengurangi biaya transportasi, 
biayalogistik, dan dapat mengefisiensikan waktu yang digunakan dalam melakukan telekomunikasi tersebut. Semua kegiatan ekonomi saat ini bisa melalui online seperti, belanja, dan transaksi lainnya. Namun, kebutuhan telekomunikasi saat ini tidak hanya sekedar telpon dan SMS, tetapi juga internet yang sudah menjadi kebutuhan untuk mendukung kegiatan masyarakat sehari-hari.

Perkembangan bisnis handphone saat ini telah menunjukkan suatu gejala yang semakin banyak dan beragamnya produk yang ditawarkan oleh perusahaan dan pengembangannya yang semakin cepat. Setiap merek produk banyak meluncurkan model dan seri yang bervariasi. Banyaknya merek yang ada dipasaran mengakibatkan perbedaan kategori produk menjadi bagian penting bagi seorang konsumen, karena karakteristik kategori produk akan mempengaruhi perilaku konsumen dalam mencari variasi yang baru (Suharseno, Hidayat, Ayu, \& Dewi, 2013)

Perpindahan merek (brand switching) ialah suatu bentuk pembelian dengan perubahan atau pergantian dari satu merek kemerek yang lain. Dengan adanya ketidakpuasan yang didapatkan oleh konsumen setelah melakukan pembelian, maka konsumen akan mencari informasi tentang produk lain yang sesuai dengan keiinginannya dan disinilah keputusan perpindahann merek terjadi. Ada beberapa faktor yang mendorong terjadinya keputusan perpindahan merek seperti, ketidakpuasan konsumen dan karakteristik kategori produk.

Ketidakpuasan konsumen dapat terjadi setelah konsumen melakukan pembelian dan dia melakukan perbandingan antara karakteristik kategori produk yang dibelinya dengan harapan-harapannya. Jika produk yang dibelinya tidak dapat memenuhi tingkat kepuasannya maka konsumen akan berpikir untuk menggunakan produk lain yang sesuai dengan keinginannya. Konsumen menggunakan informasi dari masa lalu dan masa sekarang terhadap suatu produk dalam memilih merek produk yang sesuai dengan yang mereka harapkan. Ada juga yang mencari informasi diinternet dan bertanya kepada temannya yang telah terlebih dahulu memakai produk dengan merek yang sama tentang produk yang akan dibeli tersebut. Ketidakpuasan bisa mengakibatkan konsumen mengeluh. Suatu produk dan perusahaan akan terancam ditinggalkan oleh kunsumen apabila konsumen tersebut mengeluh atas apa yang diperolehnya. Suatu perusahaan penting mempertahankan pelanggan yang sudah ada, karena biaya untuk menarik pelanggan baru jauh lebih besar dibandingkan biaya untuk mempertahankan pelanggan yang sudah ada. Agar pelanggan tidak pergi dari suatu produk hal yang harus dilakukan oleh perusahaan yaitu meningkatkan kepuasan konsumen. Pemasar harus memikirkan kepuasan dan ketidakpuasan konsumen terhadap produk karena dapat mempengaruhi perilaku konsumen selanjutnya.

Apabila konsumen pernah merasakan ketidakpuasan pada saat menggunakan suatu merek produk tertentu maka akan ada kemungkinan konsumen tersebut merubah perilaku keputusan belinya dengan mencoba produk merek lain pada konsumsi berikutnya yang sesuai dengan keinginannya untuk meningkatkan kepuasannya. Selain itu adapun hal lain yang ikut serta mempengaruhi terjadinya perilaku konsumen dalam keputusan perpindahan merek ialah karakteristik kategori produk. 
Karakteristik kategori produk, MenurutJunaidi \& Dharmmesta (2002)meliputi keterlibatan, perbedaan persepsi diantara merek, fiturhedonis, dan kekuatan preferensi. Konsumen melakukan perilaku mencari variasi hanya dilakukan untuk suatu kategori produk tertentu dan tidak untuk kategori produk yang lainnya.

Seiring dengan berjalannya waktu, kita melihat banyaknya produk hp yang dikeluarkan dengan merek yang bermacam-macam seperti, Samsung, Oppo, Iphone, dan Xiomi. Setiap produk yang dikeluarkan oleh perusahaan pasti memiliki keunggulan dan karakteristik yang berbeda dengan produk lain. Keunggulan dan karakteristik inilah yang menjadi daya tarik konsumen untuk membelinya. Setiap mahasiswa/mahasiswi pasti menggunakan produk merek hp yang berbeda, dan saya melihat banyaknya mahasiswa/mahasiswi dengan mudahnya berpindah merek hp yang dipakainya.

\section{Tabel 1}

Merek Hp dan Keunggulannya

\begin{tabular}{|c|c|c|}
\hline No & Merek Hp & Keunggulan \\
\hline 1. & Oppo & $\begin{array}{l}\text { 1. Oppo sangat terkenal memiliki baterai yang panjang } \\
\text { umur. } \\
\text { 2. Terkenal dengan fitur-fitur selfienya } \\
\text { 3. Layar Oppo kokoh dan User Interface-nya juga cantik. } \\
\text { 4. Screenshot Cuma pakai tiga jari. } \\
\text { 5. Memiliki beragam jenis. }\end{array}$ \\
\hline 2. & Samsung & $\begin{array}{l}\text { 1. Signal Max } \\
\text { 2. Biometric Recognition } \\
\text { 3. Curved Edge Display } \\
\text { 4. Bixby } \\
\text { 5. Mode glove } \\
\text { 6. Multy window }\end{array}$ \\
\hline 3. & iPhone & $\begin{array}{l}\text { 1. Jaminan Update OS lebih lama } \\
\text { 2. Aplikasi terbaik rilis lebih awal di Ios } \\
\text { 3. Performa Ios lebih baik } \\
\text { 4. Sistem operasi lebih aman } \\
\text { 5. Berbahan premium, desain simple dan elegan. } \\
\text { 6. Garansi } \\
\text { 7. Kualitas kamera terbaik } \\
\text { 8. Harga jual lebih tinggi } \\
\text { 9. Minim resiko terkena "malware" } \\
\text { 10. Tanpa aplikasi operator seluler }\end{array}$ \\
\hline 4. & Xiaomi & $\begin{array}{l}\text { 1. Theme atau tema MIUI } \\
\text { 2. Mi Cloud } \\
\text { 3. Mi Remote } \\
\text { 4. Mi Drop } \\
\text { 5. Sms time atau sms waktu }\end{array}$ \\
\hline
\end{tabular}

Berdasarkan uraian dalam latarbelakang di atas, maka dapat diambil identifikasi masalah dalam penelitian ini adalah: 
1. Apakah ketidakpuasan konsumen berpengaruh terhadap keputusan perpindahan merek pada mahasiswa program studi manajemen stie "KBP" Padang.

2. Apakah karakteristik kategori produk hp berpengaruh terhadap keputusan perpindahan merek pada mahasiswa program studi manajemen stie "KBP" Padang.

\section{TINJAUAN PUSTAKA}

\section{Keputusan Perpindahan Merek}

\section{Pengertian keputusan perpindahan merek}

MenurutRetno Dewanti a, Aryanti Puspokusumob, (2011), perpindahan merek yaitu suatu bentuk perubahan pembelian atau pergantian dari suatu merek produk ke merek yang lain.

\section{Indikator keputusan perpindahan merek}

Menurut Dwi Wahyu Pril Ranto (2000), Ada tiga indikator yang mendorong terjadinya keputusan perpindahan merek yaitu:
a. Ada/tidaknya uang
b. Switching cost
c. Kebiasaan

\section{Karakteristik Kategori Produk Hp}

\section{Pengertian Ketidakpuasan Konsumen}

Ketidakpuasan konsumen ialah salah satu alasan yang menyebabkan munculnya perpindahan merek sebab apabila pelanggan tidak puas terhadap suatu produk dan tidak sesuai dengan harapannya maka pelanggan tersebutakan mencari informasi pilihan produk lain, dan mungkin akan berhenti membeli produk yang tidak sesuaii dengan keinginan dan kebutuhannya tadi atau memprovokasi orang yang ada disekitarnya untuk tidak membeli produk tersebut(Suharseno et al., 2013).

\section{Indikator Ketidakpuasan Konsumen}

Menurut (Suharseno et al., 2013), Ada tiga indikator yang menyebabkan timbulnya ketidakpuasan konsumen:
a. Nilai
b. Manfaat
c. Keinginan

\section{Karakteristik Kategori Produk Hp}

\section{Pengertian Karakteristik Kategori Produk Hp}

Menurut Suharseno et al., (2013)karakteristik kategori produk merupakan sifat suatu produk yang dapat membedakan produk tersebut dengan produk lainnya.

\section{Indikator Karakteristik Kategori Produk Hp}

Menurut Suharseno et al., (2013), Ada empat indikator yang mendorong terjadinya karakteristik kategori produk hp:
a. Keterlibatan
b. Perbedaan Persepsi diantara Merek
c. Fiturhedonis
d. Kekuatan Preferensi 


\section{Pengembangan Hipotesis}

\section{Pengaruh Ketidakpuasan Konsumen Terhadap Keputusan Perpindahan Merek}

Menurut (Suharseno et al., 2013)dalam Setiyaningrum (2007:105) yaitu salah satu alasan yang mendorong terjadinya perpindahan merek adalah ketidakpuasan yang dirasakan konsumen terhadap suatu merek produk tertentu yang digunakan sebelumnya.

Penelitian sejenis juga dilakukan oleh (Rafita Eka Andriani \& Nindria Untarini, 2015) dengan judul "Pengaruh Ketidakpuasan Konsumen Dan Kebutuhan Mencari Variasi Terhadap Perpindahan Merek Mobille Broadband Smartfren".Variabel digunakan adalah (Y): Perpindahan Merek dan variable (X1): Ketidakpuasan Konsumen dan variabel (X2): Kebutuhan Mencari Variasi. Hasil penelitian ini menyimpulkanbahwa ketidakpuasan konsumen memiliki hubungan positif dengan perpindahan merek secara langsung, kebutuhan mencari variasi memiliki hubungan positif terhadap perpindahan merek secara langsung.

\section{Pengaruh Karakteristik Kategori Produk Hp Terhadap Keputusan Perpindahan Merek}

Menurut (Nurdin,2015), keputusan perpindahan merek dilakukan oleh konsumen sebab konsumen memiliki berbagai preferensi kategori produk, dengan berbagai preferensi yang dimiliki, konsumen mempunyai banyak pilihan mengenai produk dengan merek yang berbeda. Jadi Karakteristik kategori produk ialah interaksi konsumen dengan suatu kategori produk.

Penelitian sejenis juga dilakukan oleh Nurdin,(2015), dengan judul "Pengaruh Ketidakpuasan Konsumen, Karakteristik Kategori Produk Dan Kebutuhan Mencari Variasi Terhadap Keputusan Perpindahan Merek Sepeda Motor". Variabel digunakan adalah (Y): Keputusan Perpindahan Merek dan variabel (X1): Ketidakpuasan Konsumen dan (X2): Karakteristik Kategori Produk. Hasil penelitian ini menyimpulkan bahwa Ketidakpuasan konsumen, karakteristik kategori produk, dankebutuhan mencari variasi secara bersama-sama berpengaruh positifterhadap keputusan perpindahan merek.

\section{Hipotesis}

H1 : Diduga Ketidakpuasan Konsumen berpengaruh positif dan signifikan terhadap Keputusan Perpindahan Merek

H2 : Diduga Karakteristik Kategori Produk Hp berpengaruh positif dan signifikan terhadap keputusan Perpindahan Merek

\section{METODE PENELITIAN}

\section{Jenis Penelitian}

Jenis penelitian ini adalah Penelitian Kuantitatif, penelitian kuantitatif yaitu salah satu metode penelitian dimana data penelitian berupa angka-angka dan analisis menggunakan statistik (Sugiyono, 2015).

\section{Objek atau Lokasi Penelitian}

Menurut Sugiyono (2015) pengertian objek penelitian ialah ilmiah untuk mendapatkan sejumlah dataa dengan tujuan dan kegunaan tertentu tentang sesuatu hal objektif valid, dan reliable. Dengan demikian objek penelitian merupakan lokasi dimana untuk mendapatkan sejumlah data yang akan dilakukan peneliti 
pada Kampus AKBP "STIE" KBPPadang yang beralamat di Jalan Khatib Sulaiman, Kota Padang, Sumatera Barat.

Populasi

Populasi dalam penelitian ini ialah mahasiswa/mahasiswi regular program studi manjemen angkatan 2014-2015 STIE "KBP" Padang yang berjumlah 56 orang, dimana disini akan menguji pengaruh ketidakpuasan konsumen dan karakteristik kategori produk terhadap perpindahan merek.

Sampel

Dalam penelitian ini teknik pengambilan sampel yang digunakan adalah sampling jenuh dimana sampling jenuh adalah teknik pengambilan sampel bila semua anggota populasi digunakan sebagai sampel (Sugiyono, 2015). Sampel yang digunakan sebanyak 56 orang mahasiswa/mahasiswi regular program studi manjemen angkatan 2014-2015 STIE “KBP” Padang.

\section{Teknik Pengumpulan Data}

\section{Kuisioner}

Kuisioner merupakan teknik pengumpulan data yang dilakukan dengan cara memberi beberapa pertanyaan dan pernyataan tertulis kepada responden untuk dijawabnya (Sugiyono, 2015).

\section{Tabel 2}

Definisi Operasional Variabel

\begin{tabular}{|l|l|l|}
\hline Variabel & Definisi & Indikator \\
\hline $\begin{array}{l}\text { Ketidakpuasan } \\
\text { Konsumen (X1) }\end{array}$ & $\begin{array}{l}\text { salah satu hal yang mendorong } \\
\text { terjadinya perpindahan merek } \\
\text { karena pelanggan yang tidak } \\
\text { puas akan mencari informasi } \\
\text { pilihan produk lain }\end{array}$ & $\begin{array}{l}\text { 1. Nilai } \\
\text { 2. Manfaat } \\
\text { 3. Keinginan }\end{array}$ \\
\hline $\begin{array}{l}\text { Karakteristik } \\
\text { Kategori Produk }\end{array}$ & $\begin{array}{l}\text { sifat suatu produk yang dapat } \\
\text { membedakan produk tersebut } \\
\text { dengan produk lainnya }\end{array}$ & $\begin{array}{l}\text { 1. Keterlibatan } \\
\text { 2. Perbedaan persepsi } \\
\text { diantara merek } \\
\text { 3. Fiturhedonis } \\
\text { 4. Kekuatan } \\
\text { Preferensi }\end{array}$ \\
\hline $\begin{array}{l}\text { Keputusan } \\
\text { Perpindahan Merek }\end{array}$ & $\begin{array}{l}\text { pola pembelian dengan } \\
\text { perubahan atau pergantian dari } \\
\text { satu merek ke merek yang lain }\end{array}$ & $\begin{array}{l}\text { 1. Ada/tidaknya uang } \\
\text { 2. Switching Cost } \\
\text { 3.Kebiasaan }\end{array}$ \\
\hline
\end{tabular}

\section{Teknik Analisis Data}

\section{Uji Vadilitas}

Uji vadilitas adalah suatu langkah pengujian yang dilakukan terhadap isi (konten) dari suatu instrumen yang digunakan dalam suatu penelitian (Sugiyono, 2015). Validitas suatu butir pertanyaan dapat dilihat dari output StatisticalProgram For Social Science (SPSS) pada pada tabel dengan judul Item-Total Statistisc.Suatu butir pertanyaan dikatakan valid jika nilai dari Corrected Item-Total Corrected $>0,30$. Uji validitas sebaiknya dilakukan secara terpisah pada lembar kerja yang berbeda antara satu konstruk variabel dengan konstruk variabel yang lain sehingga dapat diketahui butir-butir pertanyaan 
variabel mana yang paling banyak tidak valid. Sehingga pengambilan keputusan adalah:

a. Jika Corrected Item-Total Correlation $>0,30$,maka dimensi tersebut valid

b. Jika Corrected Item-Total Correlation < 0,30, maka dimensi tersebut tidak valid

\section{Uji Reliabilitas}

Uji reliabilitas adalah uji terhadap instrumen yang bila digunakan beberapa kali untuk mengukur objek yang sama akan menghasilkan data yang sama (Sugiyono, 2015).Uji reabilitas dapat dilakukan secara bersama - sama terhadap seluruh butir pernyataan untuk lebih dari satu variabel, namun sebaiknya uji reliabilitas sebaliknya dilakukan pada masing - masing variabel pada lembar kerja yang berbeda sehingga dapat diketahui konstruk variabel mana yang tidak reliabel. Reliabilitas suatu konstuk variabel dikatakan baik jika memiliki nilai Cronbach's Alpha> 0,06. Sehingga pengambilan keputusan adalah :

a. Jika r Alpha positif, serta $r>0,06$ maka dimensi tersebut reliabel.

b. Jika $r$ Alpha positif, serta $r \leq 0,06$ maka dimensi tersebut tidak reliabel.

\section{Uji TCR (Tingkat Capaian Responden)}

Menghitung nilai Tingkat Capaian Responden (TCR) masing-masing kategori dari data deskriptif variabel. Rumus uji TCR (Hanum et al., 2015):

Keterangan :

$$
T C R=\frac{R s}{\mathrm{n}} \times 100 \%
$$

TCR : Tingkat Capaian Responden

RS : Rata-rata skor jawaban sampel

$\mathrm{n}$ : nilai skor jawaban

Sugiyono (2013), mengemukakan Kriteria jawaban responden untuk Tingkat Capaian Responden (TCR) adalah sebagai berikut:

Tabel 3

Rentang Skala TCR

\begin{tabular}{ccc}
\hline No & Angka & Keterangan \\
\hline 1 & $0 \%-54.9 \%$ & Tidak Baik \\
\hline 2 & $55 \%-64.9 \%$ & Kurang Baik \\
\hline 3 & $65 \%-79.9 \%$ & Cukup Baik \\
\hline 4 & $80 \%-89.9 \%$ & Baik \\
\hline 5 & $90 \%-100 \%$ & Sangat Baik \\
\hline
\end{tabular}

Sumber: Hanum et al., (2015)

\section{Uji asumsi klasik}

\section{Uji Normalitas}

Uji normalitas adalah pengujian untuk mengkaji kenormalan variabel yang diteleti apakah data tersebut berdistribusi normal atau tidak (Sugiyono, 2015). Indikator yang digunakan Uji kolmogrov-smirnov dengan pedoman yaitu:

a. Jika nilai signifikansi $>0,05$.,maka berdistribusi normal

b. Jika nilai signifikans $<0,05$, maka tidak berdistribusi normal 


\section{Uji Multikolinearitas}

Uji multikonearitas bertujuan untuk menguji apakah model regresi ditemukan adanya korelasi antar variabel bebas (independen), model regresi yang baik seharusnya tidak terjadi korelasi diantara variabel independen (Ghozali, 2011). Indikator uji multikonearitas yaitu apabila nilai tolerance $>0,1$, dan Variance Inflation Factor (VIF) $<10$ maka tidak terjadi gejala multikonearitas sehingga tidak adanya pengaruh antara variabel yang satu dengan variabel yang lainnya.

\section{Uji Heteroskedastisitas}

Uji heteroskedatisitas bertujuan menguji apakah dalam model regresi terjadi ketidaksamaan varians dari residual satu pengamatan ke pengamatan yang lain. (Ghozali, 2011). Uji yang dipakai untuk mendeteksi ada atau tidaknya masalah heteroskedatisitas, yaitu :

\section{Uji Glejser}

Salah satu cara untuk melihat adanyaproblem heteroskedastisitas adalah dengan menggunakan uji glejser, dengan ketentuan jika nilai signifikasinya $>0,05$ dapat disimpulkan model regresi tidak terjadi masalah heteroskedastisitas.

\section{Analisis Regresi Berganda}

Analisa regresi linear berganda adalah prosedur statistik untuk menganalisa hubungan antara variabel dependen dan variabel independen. Jika terdapat dua atau lebih variabel bebas maka menggunakan analisa regresi linear berganda(Prabowo \& Fathoni, 2016). Dalam penelitian ini digunakan persamaan regresi berganda sebagai berikut :

$$
\begin{aligned}
& \mathrm{Y}=\alpha+\beta 1 \mathrm{X} 1+\beta 2 \mathrm{X} 2+\mathrm{e} \\
& \mathrm{Y}=\text { Turnover Intention } \\
& \mathrm{X} 1=\text { Stres Kerja } \\
& \mathrm{X} 2=\text { Kesempatan Promosi } \\
& \alpha=\text { Koefisien Konstanta } \\
& \beta 1=\text { Koefisien regresi untuk Stres Kerja } \\
& \beta 2=\text { Koefisien untuk Kesempatan Promosi } \\
& \mathrm{e} \quad=\text { Standar } \text { error }
\end{aligned}
$$

\section{Uji Hipotesis}

\section{Uji F}

Uji Anova atau uji $\mathrm{F}$ adalah uji statistik yang fungsinya untuk mengetahui apakah secara bersamasama variabel independen mempunyai pengaruh signifikan atau tidak signifikan terhadap variabel dependen(Ardi \& Ninik Sukmasari, 2016). Dengan kriteria yang ditetapkan adalah :

a. Nilai Sig<0,05 artinya secara bersama-sama ada pengaruh yang signifikan di antara seluruh variabel independen yang diuji terhadap variabel dependennya.

b. Nilai Sig >0,05 artinya secara bersama-sama tidak ada pengaruh yang signifikan diantara seluruh variabel independen yang diuji terhadap variabel dependennya.

\section{Uji T}

Menurut Sugiyono (2015), uji statistik t pada dasarnya menunjukkan seberapa jauh pengaruh satu variabel independen secara individual dalam menerangkan variabel dependen. Pengujian dilakukan dengan menggunakan signifikan level $0,05(\alpha=5 \%)$. Penerimaan atau penolakan hipotesis dilakukan dengan kriteria: 
a. Jika nilai signifikan $>0,05$ maka hipotesis ditolak (koefisien regresi tidak signifikan). Ini berarti secara parsial variabel independen tidak mempunyai pengaruh secara signifikan terhadap variabel dependen.

b. Jika nilai signifikan $\leq 0,05$ maka hipotesis diterima (koefisien regresi signifikan). Ini berarti secara parsial variabel independen tersebut mempunyai pengaruh yang signifikan terhadap variabel dependen.

\section{HASIL DAN PEMBAHASAN}

\section{Teknik Analisis Data}

\section{Uji Validitas}

Tabel 4

Uji Validitas Variabel Ketidakpuasan Konsumen (X1)

\begin{tabular}{|c|c|c|c|}
\hline & $\begin{array}{c}\text { Corrected Item-Total } \\
\text { Correlation }\end{array}$ & Standar Pengukuran & Ket \\
\hline Kk1 & 0,870 & 0,30 & Valid \\
\hline Kk2 & 0,873 & 0,30 & Valid \\
\hline Kk3 & 0,831 & 0,30 & Valid \\
\hline Kk4 & 0,799 & 0,30 & Valid \\
\hline Kk5 & 0,741 & 0,30 & Valid \\
\hline Kk6 & 0,832 & 0,30 & Valid \\
\hline Kk7 & 0,833 & 0,30 & Valid \\
\hline Kk8 & 0,790 & 0,30 & Valid \\
\hline Kk9 & 0,699 & 0,30 & Valid \\
\hline Kk10 & 0,809 & 0,30 & Valid \\
\hline
\end{tabular}

Sumber : Data SPSS 16 (Data diolah tahun 2018)

Berdasarkan hasil dari perhitungan uji validitas variabel X1 (ketidakpuasan konsumen) terhadap 56 responden, didapatkan bahwa semua butir pernyataan dinyatakan valid. Hal ini ditunjukkan dengan nilai Corrected ItemTotal Correlation yang lebih besar dari 0,30, sehingga belum dapat dilakukan untuk penelitian lebih lanjut. 
Tabel 5

Uji Validitas Variabel Karakteristik Kategori Produk Hp (X2)

\begin{tabular}{|r|r|r|r|}
\hline & $\begin{array}{c}\text { Corrected Item-Total } \\
\text { Correlation }\end{array}$ & Standar Pengukuran & Keterangan \\
\hline KKPHP1 & 0,834 & 0,30 & Valid \\
\hline KKPHP2 & 0,779 & 0,30 & Valid \\
\hline KKPHP3 & 0,693 & 0,30 & Valid \\
\hline KKPHP4 & 0,438 & 0,30 & Valid \\
\hline KKPHP5 & 0,774 & 0,30 & Valid \\
\hline KKPHP6 & 0,834 & 0,30 & Valid \\
\hline KKPHP7 & 0,695 & 0,30 & Valid \\
\hline KKPHP8 & 0,405 & 0,30 & Valid \\
\hline KKPHP9 & 0,596 & 0,30 & Valid \\
\hline KKPHP10 & 0,873 & 0,30 & Valid \\
\hline KKPHP11 & 0,771 & 0,30 & Valid \\
\hline KKPHP12 & 0,678 & 0,30 & \\
\hline
\end{tabular}

Sumber : Data SPSS 16 (Data diolah tahun 2018)

Berdasarkan hasil dari perhitungan uji validitas variabel X2 (Karakteristik kategori produk hp) terhadap 56 responden, didapatkan bahwa semua butir pernyataan dinyatakan valid. Hal ini ditunjukkan dengan nilai Corrected ItemTotal Correlation yang lebih besar dari 0,30, sehingga dapat dilakukan untuk penelitian lebih lanjut.

Tabel 6

Uji Validitas Variabel Keputusan Perpindahan Merek (Y)

\begin{tabular}{|l|r|r|r|}
\hline & $\begin{array}{c}\text { Corrected Item-Total } \\
\text { Correlation }\end{array}$ & Standar Pengukuran & Keterangan \\
\hline Kpm1 & 0,869 & 0,30 & Valid \\
\hline Kpm2 & 0,889 & 0,30 & Valid \\
\hline Kpm3 & 0,834 & 0,30 & Valid \\
\hline Kpm4 & 0,845 & 0,30 & Valid \\
\hline Kpm5 & 0,920 & 0,30 & Valid \\
\hline Kpm6 & 0,809 & 0,30 & Valid \\
\hline Kpm7 & 0,899 & 0,30 & Valid \\
\hline
\end{tabular}

Sumber : Data SPSS 16 (Data diolah tahun 2018)

Berdasarkan hasil dari perhitungan uji validitas variabel $\mathrm{Y}$ (Keputusan Perpindahan Merek) terhadap 56 responden, didapatkan bahwa semua butir pernyataan dinyatakan valid. Hal ini ditunjukkan dengan nilai Corrected ItemTotal Correlation yang lebih besar dari 0,30, sehingga dapat dilakukan untuk penelitian lebih lanjut. 


\section{Uji Reliabilitas}

Tabel 7

Uji Reliabilitas

\begin{tabular}{|l|l|c|c|}
\hline No & \multicolumn{1}{|c|}{ Variabel } & Cronbach's Alpha & Reliabilitas \\
\hline 1. & Ketidakpuasan Konsumen & 0,955 & Reliabel \\
\hline 2. & Karakteristik Kategori Produk & 0,930 & Reliabel \\
\hline 3. & Keputusan Perpindahan Merek & 0,960 & Reliabel \\
\hline
\end{tabular}
Sumber : Data SPSS 16 (Data diolah tahun 2018)

Dari hasil uji reliabilitas, dihasilkan nilai Cronbach's Alpha untuk variabel penelitian Ketidakpuasan Konsumen, Karakteristik Kategori Produk, dan Keputusan Perpindahan Mereklebih dari 0,60 yang memberikan hasil bahwa variabel yang diteliti dapat dikatakan reliabilitas.

\section{Uji TCR}

Tabel 8

Deskripsi Variabel Ketidakpuasan Konsumen (X1)

\begin{tabular}{|c|c|c|c|c|c|c|c|c|c|c|c|c|}
\hline Indikator & No. Item & ss & $\mathbf{S}$ & KS & TS & STS & $\mathbf{N}$ & $\%$ & Skor Total & Rata-rata & TCR (\%) & Kriteria \\
\hline \multirow{10}{*}{$\begin{array}{l}\text { Ketidakpuasa } \\
\text { n Konsumen }\end{array}$} & 1 & 6 & 36 & 3 & 10 & 1 & 56 & 100 & 204 & 3,64 & 72,86 & Cukup Baik \\
\hline & 2 & 15 & 25 & 6 & 8 & 2 & 56 & 100 & 211 & 3,77 & 75,36 & Cukup Baik \\
\hline & 3 & 9 & 28 & 10 & 8 & 1 & 56 & 100 & 204 & 3,64 & 72,86 & Cukup Baik \\
\hline & 4 & 8 & 20 & 14 & 10 & 4 & 56 & 100 & 186 & 3,32 & 66,43 & Cukup Baik \\
\hline & 5 & 17 & 21 & 10 & 7 & 1 & 56 & 100 & 214 & 3,82 & 76,43 & Cukup Baik \\
\hline & 6 & 10 & 29 & 11 & 4 & 2 & 56 & 100 & 209 & 3,73 & 74,64 & Cukup Baik \\
\hline & 7 & 15 & 20 & 10 & 9 & 2 & 56 & 100 & 205 & 3,66 & 73,21 & Cukup Baik \\
\hline & 8 & 10 & 20 & 17 & 7 & 2 & 56 & 100 & 197 & 3,52 & 70,36 & Kurang Baik \\
\hline & 9 & 3 & 7 & 32 & 12 & 2 & 56 & 100 & 165 & 2,95 & 58,93 & Kurang Baik \\
\hline & 10 & 13 & 23 & 8 & 10 & 2 & 56 & 100 & 203 & 3,63 & 72,50 & Cukup Baik \\
\hline & \multicolumn{10}{|c|}{ Rata-rata TCR } & 71,36 & Cukup Baik \\
\hline
\end{tabular}

Sumber : Data SPSS 16 (Data diolah tahun 2018)

Dari tabel diatas maka dapat dilihat bahwa item pernyataan nomor sembilan merupakan persentase paling rendah sebesar $58,93 \%$ dan item pernyataa nomor lima merupakan persentase paling tinggi sebesar 76,43\%. Kesimpulan ratarata dari tanggapan responden terhadap variabel ketidakpuasan konsumen berada pada tingkatan Cukup Baik, yaitu sebesar 71,36\%. 
Tabel 9

Deskripsi Variabel Karakteristik Kategori Produk Hp (X2)

\begin{tabular}{|c|c|c|c|c|c|c|c|c|c|c|c|c|}
\hline Indikator & $\begin{array}{l}\text { No. } \\
\text { Item }\end{array}$ & SS & $\mathbf{S}$ & KS & TS & STS & $\mathbf{N}$ & $\%$ & Skor Total & Rata-rata & TCR & Kriteria \\
\hline \multirow{12}{*}{$\begin{array}{c}\text { Karakteristik } \\
\text { Kategori } \\
\text { Produk Hp }\end{array}$} & 1 & 14 & 28 & 8 & 4 & 2 & 56 & 100 & 216 & 3,86 & 77,14 & Cukup Baik \\
\hline & 2 & 24 & 14 & 11 & 5 & 2 & 56 & 100 & 221 & 3,95 & 78,93 & Cukup Baik \\
\hline & 3 & 16 & 28 & 7 & 4 & 1 & 56 & 100 & 222 & 3,96 & 79,29 & Cukup Baik \\
\hline & 4 & 3 & 8 & 34 & 8 & 3 & 56 & 100 & 168 & 3,00 & 60,00 & Kurang Baik \\
\hline & 5 & 28 & 14 & 7 & 5 & 2 & 56 & 100 & 229 & 4,09 & 81,79 & Baik \\
\hline & 6 & 6 & 32 & 10 & 5 & 3 & 56 & 100 & 201 & 3,59 & 71,79 & Cukup Baik \\
\hline & 7 & 10 & 25 & 14 & 7 & 0 & 56 & 100 & 206 & 3,68 & 73,57 & Cukup Baik \\
\hline & 8 & 5 & 20 & 20 & 7 & 4 & 56 & 100 & 183 & 3,27 & 65,36 & Cukup Baik \\
\hline & 9 & 22 & 26 & 5 & 3 & 0 & 56 & 100 & 235 & 4,20 & 83,93 & Baik \\
\hline & 10 & 6 & 36 & 3 & 10 & 1 & 56 & 100 & 204 & 3,64 & 72,86 & Cukup Baik \\
\hline & 11 & 16 & 25 & 6 & 8 & 2 & 56 & 100 & 216 & 3,86 & 77,14 & Cukup Baik \\
\hline & 12 & 9 & 28 & 10 & 8 & 1 & 56 & 100 & 204 & 3,64 & 72,86 & Cukup Baik \\
\hline & & & & & & Rata- & TCR & & & & 74,55 & Cukup Baik \\
\hline
\end{tabular}

Sumber : Data SPSS 16 (Data diolah tahun 2018)

Dari tabel diatas maka dapat dilihat bahwa item pernyataan nomor empat merupakan persentase paling rendah sebesar $60,00 \%$ dan item pernyataan nomor sembilan merupakan persentase paling tinggi sebesar $83,93 \%$. Kesimpulan ratarata dari tanggapan responden terhadap variabel karakteristik kategori produk hp berada pada tingkatan Cukup Baik, yaitu sebesar 74,55\%

\section{Tabel 10}

Deskripsi Variabel Keputusan Perpindahan Merek (Y)

\begin{tabular}{|c|c|c|c|c|c|c|c|c|c|c|c|c|}
\hline Indikator & $\begin{array}{c}\text { No. } \\
\text { Item }\end{array}$ & SS & $\mathbf{S}$ & KS & TS & STS & $\mathbf{N}$ & $\%$ & Skor Total & Rata-rata & TCR & Kriteria \\
\hline \multirow{7}{*}{$\begin{array}{l}\text { Keputusan } \\
\text { Perpindahan } \\
\text { Merek (Y) }\end{array}$} & 1 & 3 & 18 & 8 & 18 & 9 & 56 & 100 & 156 & 2,79 & 55,71 & Kurang Baik \\
\hline & 2 & 7 & 18 & 5 & 14 & 12 & 56 & 100 & 162 & 2,89 & 57,86 & Kurang Baik \\
\hline & 3 & 5 & 15 & 10 & 19 & 7 & 56 & 100 & 160 & 2,86 & 57,14 & Kurang Baik \\
\hline & 4 & 4 & 14 & 12 & 16 & 10 & 56 & 100 & 154 & 2,75 & 55,00 & Cukup Baik \\
\hline & 5 & 12 & 13 & 4 & 4 & 23 & 56 & 100 & 155 & 2,77 & 55,36 & Kurang Baik \\
\hline & 6 & 5 & 14 & 14 & 13 & 10 & 56 & 100 & 159 & 2,84 & 56,79 & Kurang Baik \\
\hline & 7 & 10 & 16 & 2 & 17 & 11 & 56 & 100 & 165 & 2,95 & 58,93 & Kurang Baik \\
\hline
\end{tabular}

Sumber : Data SPSS 16 (Data diolah tahun 2018)

Dari tabel diatas maka dapat dilihat bahwa item pernyataan nomor empat merupakan persentase paling rendah sebesar 55,00\% dan item pernyataan nomor tujuh merupakan persentase paling tinggi sebesar 58,68\%. Kesimpulan rata-rata dari tanggapan responden terhadap variabel keputusan perpindahan merek berada pada tingkatan Kurang Baik, yaitu sebesar 56,68\%

Uji asumsi Klasik

Tabel 11

Uji Normalitas

\begin{tabular}{|l|c|}
\hline & Standardized Residual \\
\hline Kolmogorov-Smirnov Z & 1.035 \\
\hline Asymp. Sig. (2-tailed) & 0,234 \\
\hline
\end{tabular}

Sumber : Data SPSS 16 (Data diolah tahun 2018) 
Dengan data yang dapat dilihat berdasarkan hasil olahan data diatas bahwa nilai signifikansi sebesar 0,234>0,05, sehingga dapat ditarik kesimpulan bahwa data yang diolah berdistribusi normal.

Tabel 12

Uji Multikolinearitas

\begin{tabular}{|l|r|r|}
\hline \multirow{2}{*}{ Model } & \multicolumn{2}{|c|}{ Collinearity Statistics } \\
\cline { 2 - 3 } & Tolerance & \multicolumn{1}{|c|}{ VIF } \\
\hline (Constant) & 0,365 & 2.743 \\
Ln_X1 & 0,365 & 2.743 \\
Ln_X2 & & \\
\end{tabular}

Sumber : Data SPSS 16 (Data diolah tahun 2018)

Berdasarkan uji multikonearitas bahwa menunjukkan nilai tolerance dari setiap variabel bebas $0,365>0,1$ dan nilai VIF $2.743<10$, maka kesimpulannya tidak terjadi masalah multikonearitas.

\section{Uji Heteroskedatisitas}

Tabel 13

Uji Glejser

\begin{tabular}{|c|c|c|c|c|c|c|}
\hline \multirow{2}{*}{\multicolumn{2}{|c|}{ Model }} & \multicolumn{2}{|c|}{ Unstandardized Coefficients } & \multirow{2}{*}{$\begin{array}{c}\text { Standardized } \\
\text { Coefficients }\end{array}$} & \multirow[b]{2}{*}{$\mathrm{T}$} & \multirow[b]{2}{*}{ Sig. } \\
\hline & & B & $\begin{array}{l}\text { Std. } \\
\text { Error }\end{array}$ & & & \\
\hline 1 & (Constant) & -1.155 & .405 & & -2.851 & .006 \\
\hline & Ln_X1 & .214 & .141 & .301 & 1.517 & .135 \\
\hline & Ln_X2 & .189 & .177 & .212 & 1.068 & .291 \\
\hline
\end{tabular}

Sumber : Data SPSS 16 (Data diolah tahun 2018)

Berdasarkan hasil uji gletser diatas dapat diketahui bahwa nilai signifikan Ketidakpuasan Konsumen (Ln_X1) 0,269 > 0,05 dan nilai signifikan Karakteristik Kategori Produk Hp (Ln_X2) 0,959 > 0,05, maka dapat disimpulkan model regresi tidak mengandung masalah heteroskedatisitas.

\section{Analisis Regresi Linear Berganda}

Tabel 14

Hasil Uji Regresi Linear Berganda

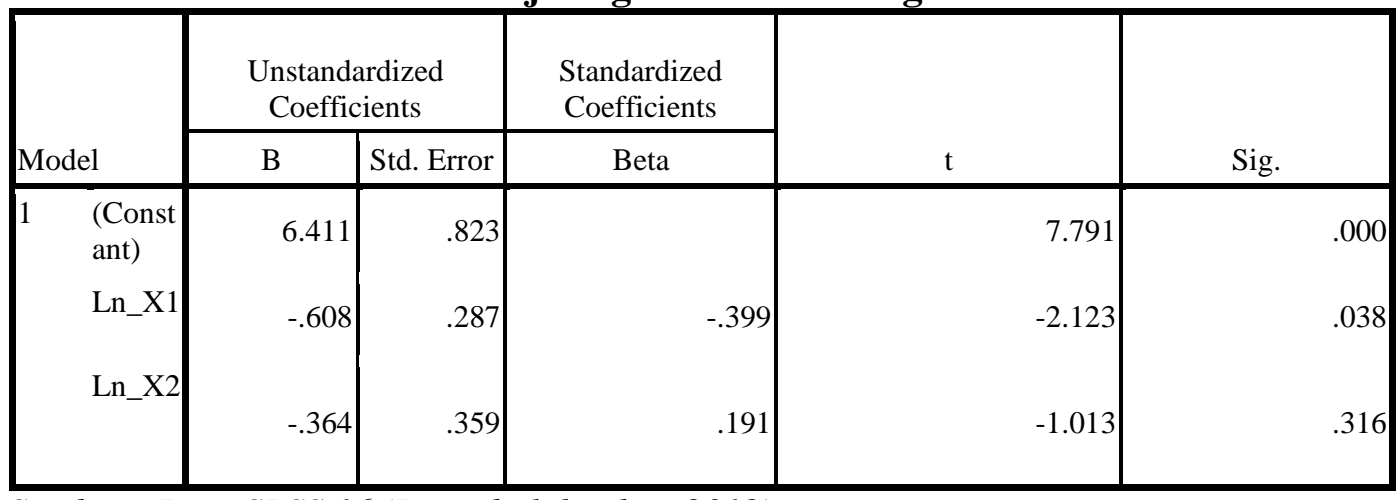

Sumber : Data SPSS 16 (Data diolah tahun 2018) 
Berdasarkan hasil regresi yang didapat maka dibuat persamaan linear berganda sebagai berikut :

$\mathrm{Y}=6.411-0,608(\mathrm{X} 1)-0,364(\mathrm{X} 2)+\mathrm{e}$

Persamaan regresi linear berganda diatas mempunyai arti sebagai berikut :

1. Konstanta mempunyai nilai positif sebesar 6.411. Hal ini berarti apabila ketidakpuasan konsumen dan karakteristik kategori produk hp mahasiswa regular program manajemen angkatan 2014-2015 Stie "Kbp" Padang bernilai nol, maka keputusan perpindahan merek mahasiswa masih bernilai tetap 6.411.

2. Nilai koefisien regresi ketidakpuasan konsumen (Ln_X1) adalah $-0,608$ artinya apabila ketidakpuasan konsumen meningkat sebesar satu satuan, maka keputusan perpindahan merek berkurang -0,608.

3. Nilai koefisien regresi karakteristik kategori produk hp (Ln_X2) adalah -0,364 artinya apabila karakteristik kategori produk hp meningkat satu satuan maka keputusan perpindahan merek berkurang $-0,364$.

\section{Uji Hipotesis}

\section{Tabel 15}

Uji F

\begin{tabular}{|l|r|r|r|r|r|}
\hline \multicolumn{1}{l|}{ Model } & Sum of Squares & Df & Mean Square & F & Sig. \\
\hline $1 \quad$ Regression & 3.763 & 2 & 1.882 & 12.291 & $.000^{\mathrm{a}}$ \\
Residual & 8.114 & 53 & .153 & & \\
Total & 11.877 & 55 & & & \\
\hline
\end{tabular}

Sumber : Data SPSS 16 (Data diolah tahun 2018

Dari tabel diketahui hasil uji f sebesar 12.291 dan nilai signifikan sebesar 0,000 . Hal ini berarti nilai signifikan $\mathrm{f}$ sebesar $0,000<0,05$, menunjukkan variabel ketidakpuasan konsumen dan karakteristik kategori produk hp artinya secara bersama-sama memiliki pengaruh yang signifikan diantara seluruh variabel independen yang diuji terhadap variabel dependennya.

\section{Tabel 16}

Uji T

\begin{tabular}{|c|c|c|c|}
\hline & Model & $\mathrm{T}$ & Sig. \\
\hline 1 & (Constant) & 7.791 & .000 \\
\hline & Kk : ketidakpuasan konsumen & -2.123 & .038 \\
\hline & Kkphp : karakteristik kategori produk hp & -1.013 & .316 \\
\hline
\end{tabular}

Sumber : Data SPSS 16 (Data diolah tahun 2018)

Berdasarkan hasil uji t pada tabel dapat dilkakukan analisa sebagai berikut

1. Hasil uji t ketidakpuasan konsumen terhadap keputusan perpindahan merek diperoleh thitung $-2.123<2.021$ dan nilai signifikansi sebesar 0,038 . Hal ini menunjukkan adanya pengaruh yang negatif dan signifikan 0,038<0,05. Sehingga menerima hipotesis yang menyatakan ketidakpuasan konsumen berpengaruh terhadap keputusan perpindahan merek.

2. Hasil uji t karakteristik kategori produk hp terhadap keputusan perpindahan merek diperoleh thitung $-1.013<2.021$ dan nilai signifikansi sebesar 0,316. Hal ini menunjukkan adanya pengaruh yang negatif dan tidak signifikan 0,316 $>0,05$. Sehingga menolak hipotesis yang menyatakan karakteristik kategori produk hp berpengaruhterhadap keputusan perpindahan merek . 


\section{PEMBAHASAN}

1. Pengaruh Ketidakpuasan Konsumen Terhadap Keputusan Perpindahan Merek pada Mahasiswa Regular Program Studi Manajemen Angkatan 2014-2015 STIE “KBP” Padang

Berdasarkan hasil pengujian hipotesis pertama, ditemukan bahwa variabel ketidakpuasan konsumen berpengaruh negatif dan tidak signifikan terhadap keputusan perpindahan merek pada mahasiswa regular program studi manajemen angkatan 2014-2015 STIE "KBP”. Berdasarkan hasil uji t pada variabel ketidakpuasan konsumen sebesar -2.123 dan signifikansinya sebesar 0,038 yang lebih kecil dari 0,05 . Hal ini dapat diartikan bahwa variabel ketidakpuasan konsumen berpengaruh negatif dan signifikan terhadap keputusan perpindahan merek, dengan demikian hipotesis pertama (H1) dalam penelitian ini yang menyatakan bahwa ketidakpuasan konsumen tidak berpengaruh positif dan signifikan terhadap keputusan perpindahan merek pada mahasiswa regular program studi manajemen angkatan 2014-2015 Stie "Kbp" Padang, dinyatakan diterima.

Hasil penelitian ini sama dengan penelitian (Rafita Eka Andriani \& Nindria Untarini, 2015)yang menunjukkan bahwa ketidakpuasan konsumen memiliki pengaruh yang positif dan signifikan terhadap keputusan perpindahan merek.

2. Pengaruh Karakteristik Kategori Produk Hp Terhadap Keputusan Perpindahan Merek pada Mahasiswa Regular Program Studi Manajemen Angkatan 2014-2015 STIE “KBP” Padang

Berdasarkan hasil pengujian hipotesis kedua, ditemukan bahwa variabel karakteristik kategori produk berpengaruh negatif dan tidak signifikan terhadap keputusan perpindahan merek pada Pada mahasiswa regular program studi manajemen angkatan 2014-2015 STIE "KBP" Padang. Berdasarkan hasil uji t variabel karakteristik kategori produk sebesar -1.013 dan signifikansinya sebesar 0,316 yang lebih besar dari 0,05. Hal ini dapat diartikan bahwa variabel karakteristik kategori produk hp berpengaruh negatif dan tidak signifikan terhadap keputusan perpindahan merek, dengan demikian, hipotesis kedua (H2) dalam penelitian ini yang menyatakan bahwa karakteristik kategori produk $\mathrm{hp}$ berpengaruh negatif dan tidak signifikan terhadap keputusan perpindahan merek pada mahasiswa regular program studi manajemen angkatan 2014-2015 Stie "Kbp" Padang, dinyatakan ditolak.

Hal ini bermakna tingkat keputusan perpindahan merek akan tetap terjadi pada mahasiswa regular program studi manajemen angkatan 2014-2015 Stie "Kbp" Padang, meskipun ada atau tidaknya tingkat karakteristik kategori produk hp tersebut. Penelitian sejenis ini sebelumya juga dilakukan oleh Nurdin, (2015) menjelaskan bahwa karakteristik kategori produk hp berpengaruh positif dan signifikan terhadap keputusan perpindahan merek sepeda motor. 


\section{SIMPULAN}

Dari hasil pengujian hipotesis yang telah dilakukan mengenai analisis Pengaruh Ketidakpuasan konsumen, Karakteristik Kategori Produk Hp terhadap Keputusan Perpindahan Merek pada mahasiswa regular program studi manajemen angkatan 2014-2015 Stie "Kbp" Padang maka dapat ditarik kesimpulan sebagai berikut:

1. Berdasarkan penelitian yang dilakukan, menunjukkan bahwan ketidakpuasan konsumen berpengaruh negative dan tidak signifikan terhadap keputusan perpindahan merek pada mahaiswa regular program studi manajemen angkatan 2014-2015 Stie "Kbp" Padang. Ini dapat dilihat dari hasil uji t ketidakpuasan konsumen terhadap keputusan perpindahan merekdiperoleh t hitung $-2.123<$ 2.021 dan nilai signifikansi sebesar 0,038. Hal ini menunjukkan adanya pengaruh yang negatif dan signifikan $0,038>0,05$. Sehingga menerima hipotesis $\left(\mathrm{H}_{1}\right)$ yang menyatakan ketidakpuasan konsumen berpengaruh terhadap keputusan perpindahan merek.

2. Berdasarkan hasil penelitian yang dilakukan, menunjukkan bahwa karakteristik kategori produk berpengaruh positif dan tidak signifikan terhadap keputusan perpindahan merek pada mahasiswa regular program studi manajemen angkatan 2014-2015 Stie "Kbp" Padang. Ini dapat dilihat dari hasil uji t karakteristik kategori produk hp terhadap keputusan perpindahan merekdiperoleh thitung $-1.013<2.021$ dan nilai signifikansi sebesar 0,316 . Hal ini menunjukkan adanya pengaruh yang negatif dan tidak signifikan 0,316 > 0,05. Sehingga menolak hipotesis $\left(\mathrm{H}_{2}\right)$ yang menyatakan karakteristik kategori produk hpberpengaruh terhadap keputusan perpindahan merek .

\section{UCAPAN TERIMAKASIH}

Dengan selesainya penulisan artikel ini, penulis mengucapkan terima kasih kepada pihak-pihak yang membantu selama proses penulisan.

1. Bapak Febryandhie Ananda, SE, M.Si, selaku Ketua di STIE "KBP” Padang.

2. Ibu Lidya Martha, SE, MM selaku Wakil Ketua di STIE "KBP” Padang.

3. Ibu Febsri Susanti, SEI, MM selaku Ketua Program Studi Manajemen di STIE "KBP" Padang.

4. Ibu Maria Magdalena, S.Pd, MM, selaku Penasehat Akademik Program Studi Manajemen di STIE “KBP” Padang.

5. Ibu Riri Mayliza, SE, MM, selaku Pembimbing Proposal Skripsi di STIE "KBP” Padang

\section{DAFTAR PUSTAKA}

Andika, A., \& Susanti, F. (2018). Pengaruh Marketing Mix Terhadap Keputusan Pembelian Parfum di Azzwars Parfum Lubeg Padang. https://doi.org/10.31227/osf.io/upgc3

Aziz, N. (2019). Analisis Pengaruh Kualitas Produk, Harga, Promosi Terhadap Keputusan Pembelian Air Minum Dalam Kemasan (AMDK) Merek Aicos $\begin{array}{llll}\text { Produksi } & \text { PT. } & \text { Bumi } & \text { Sarimas }\end{array}$ 
https://doi.org/10.17605/OSF.IO/8XKYB Aziz, N. (2019). Pengaruh Atribut Produk Terhadap Minat Beli Sepeda Motor Honda Dealer Amanah Lubuk Alung. https://doi.org/10.17605/OSF.IO/BNDAE

Darussalam, Sambhoja. (2002). Pengaruh Ketidakpuasan Konsumen, Karakteristik Kategori Produk Dan Kebutuhan Mencari Variasi Terhadap Keputusan Perpindahan Merek Produk Smartphone (Studi Kasus Pada Perpindahan Merek Blackberry Ke Android Samsung). Jurnal Ekonomi Dan Bisnis, 17(Januari), 91-104. Https://Doi.Org/10.22146/Jieb.6707

F., \& Afriyeni, A. (2019). Aktivitas Pemasaran Produk Tabungan Pada PT. Bank Pembangunan Daerah (BPD) Sumatera Barat Cabang Utama Padang. https://doi.org/10.31219/osf.io/tf2bz

Fransiskus Gunawan. (N.D.). Pengaruh Persepsi Merek Dan Kepercayaan Konsumen Atas Produk Terhadap Brand Switching Atas Produk Smartphone (Blackberry) Pada Mahasiswa Unp, 1-11.

Ghozali, I. (2011). Aplikasi Analisis Multivariate Dengan Program Ibm Spss 20. In Book (Pp. 1-298). Semarang: Badan Penerbit Universitas Diponegoro.

Junaidi, Shellyana, \& Dharmmesta, Basu Swastha. (2002). Pengaruh Ketidakpuasan Konsumen, Karakteristik Kategori Produk, Dan Kebutuhan Mencari Variasi Terhadap Keputusan Perpindahan Merek, 17(1), 91-104.

Kamener, D. (2017). Faktor - Faktor Yang Mempengaruhi Kualitas Strategi Bersaing Industri Ukm Bordiran / Sulaman Di Kota Padang. Journal Of Economic And Economic Education, 5(1), 90-105. Https://Doi.Org/Doi.Org/10.22202/Economica.2015.5.1.688

Khasanah, Aulia Uswatun, \& Kuswati, Rini. (2013). Analisis Faktor-Faktor Yang Mempengaruhi Perpindahan Merek Pada Produk Smartphone, 17, 123-131.

Marlius, D. (2017). Keputusan Pembelian Berdasarkan Faktor Psikologis Dan Bauran Pemasaran Pada PT. Intercom Mobilindo Padang. Jurnal Pundi. Volume 1. No. 1. Hal. 57-66. https://doi.org/10.31575/jp.v1i1.9

Marlius, D. (2016). Pengaruh Bauran Pemasaran Jasa Terhadap Minat Nasabah Dalam Menabung Pada Bank Nagari Cabang Muaralabuh. https://doi.org/10.31227/osf.io/vdqgx

Mayliza, R. (2019). Pengaruh Citra Perusahaan (Corporate Image) Dan Penanganan Keluhan (Complaint Handling) Terhadap Loyalitas Pelanggan (Loyality) Natasha Skin Care Di Kota Padang. https://doi.org/10.17605/OSF.IO/DF9XJ 
Mayliza, R. (2019). Pengaruh Kesadaran Merek, Asosiasi Merek Dan Perception Of Quality Terhadap Keputusan Pembelian Hospital Bed Merek Paramout Di PT. Aga Medika Utama Padang (Studi Kasus Rumah Sakit Umum Kota Padang). https://doi.org/10.17605/OSF.IO/VYQ4E

Nurdin, M. (2015). Pengaruh Ketidakpuasan Konsumen, Karakteristik Kategori Produk, Dan Kebutuhanmencari Variasi Terhadap Keputusan Perpindahan Merek Sepedamotor.

Retno Dewanti A, Aryanti Puspokusumob, R. K. (2011). Analisis Karakteristik Produk Dan Kebutuhan Variasi Produk Dalam Mempengaruhi Perpindahan Merek Air Mineral Vit, (2089), 565-578.

Sugiyono. (2015). Statistik Nonparametris Untuk Penelitian. Yogyakarta.

Suharseno, T., Hidayat, R., Ayu, D., \& Dewi, L. (2013). Pengaruh Ketidakpuasan Konsumen Dan Karakteristik Kategori Produk Terhadap Keputusan Perpindahan Merek Dengan Kebutuhan Mencari Variasi Sebagai Variabel Moderasi, 18(2), 176-182.

Widayati, R. (2019). Aktivitas Pemasaran Produk Simpanan PT. Bank Tabungan Negara (Persero)Tbk Kantor Cabang Padang. https://doi.org/10.17605/OSF.IO/3Z5YC

Widayati, R. (2019). Aktivitas Pemasaran Produk Tabungan Pada PT. Bpr Rangkiang Denai Payakumbuh Barat. https://doi.org/10.17605/OSF.IO/S3UZM 